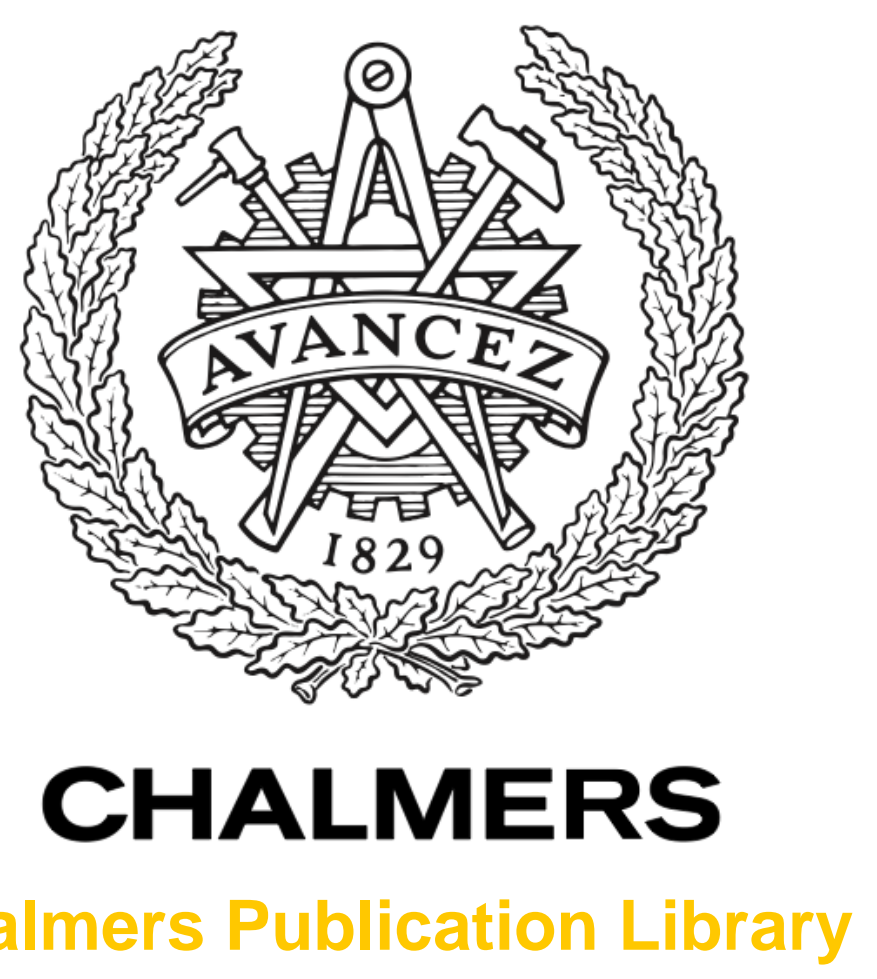

Challmers Publication Library

\title{
Co-Combustion of Sludge with Coal or Wood
}

This document has been downloaded from Chalmers Publication Library (CPL). It is the author's version of a work that was accepted for publication in:

International Journal of Power and Energy Systems (ISSN: 1078-3466)

Citation for the published paper:

Leckner, B. ; Åmand, L. (2004) "Co-Combustion of Sludge with Coal or Wood".

International Journal of Power and Energy Systems, vol. 24(3), pp. 172-178.

Downloaded from: http://publications.lib.chalmers.se/publication/238724

Notice: Changes introduced as a result of publishing processes such as copy-editing and formatting may not be reflected in this document. For a definitive version of this work, please refer to the published source. Please note that access to the published version might require a subscription.

Chalmers Publication Library (CPL) offers the possibility of retrieving research publications produced at Chalmers University of Technology. It covers all types of publications: articles, dissertations, licentiate theses, masters theses, conference papers, reports etc. Since 2006 it is the official tool for Chalmers official publication statistics. To ensure that Chalmers research results are disseminated as widely as possible, an Open Access Policy has been adopted.

The CPL service is administrated and maintained by Chalmers Library. 


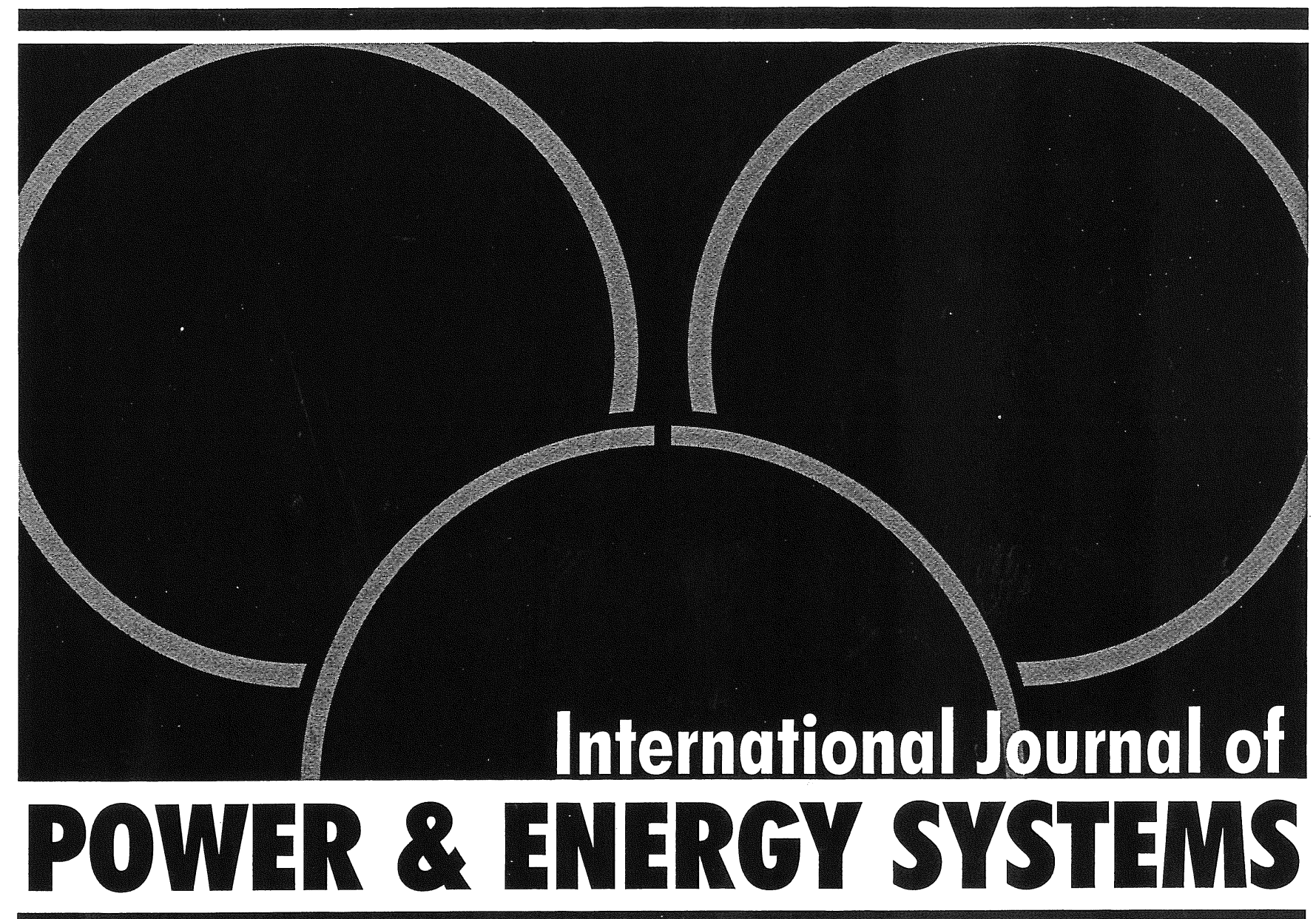

VOLUME 24, Number 3, 2004 Special Issue on Co-Utilization of Domestic Fuels (CDF)

- Editor's Note

- Reducing GHG Emissions by Co-Utilization of Coal with Natural Gas or Biomass

- $\quad$ R\&D Incentives and Co-Utilization: Electricity Market Performance

- Comparison of Concepts for Thermal Biomass Utilization, with the Examples of The Netherlands

- Co-Combustion of Sludge with Coal or Wood

- The Energy Structure and the Technology of Co-Firing Biomass and Coal in China

- Valorization of Selected Biomass and Wastes by Co-Pyrolysis with Coal

R. Moliner, M.J. Lázaro, I. Suelves, M.J. Blesa

- Advanced Technologies for Co-Processing Fossil and Biomass Resources for Transportation Fuels and Power Generation 


\title{
CO-COMBUSTION OF SLUDGE WITH COAL OR WOOD
}

\author{
B. Leckner* and L.-E. Åmand*
}

\begin{abstract}
There are several options for co-combustion of biomass or waste with coal. In all cases the fuel properties are decisive for the success of the arrangement: contents of volatile matter and of potential emission precursors, such as sulphur, nitrogen, chlorine, and heavy metals. The content of alkali in the mineral substance of the fuel is important because of the danger of fouling and corrosion. Research activities at Chalmers University of Technology include several aspects of the related problem areas. An example is given concerning emissions from co-combustion in circulating fluidized bed with coal or wood as base fuels, and with sewage sludge as additional fuel. Two aspects of the properties of sludge are studied: emissions of nitrogen and sulphur oxides as well as of chlorine, because the contents of the precursors to these emissions are high. The possibility of utilizing the phosphorous in sludge as a fertilizer is also discussed. The results show that emissions can be kept below existing emission limits if the fraction of sludge is sufficiently small $(<25 \%)$, but the concentration of trace elements in the sludge ash prevents the sludge from being used as a fertilizer.
\end{abstract}

\section{Key Words}

Co-combustion, co-firing, sludge, emissions, fluidized bed combustion, phosphorous

\section{Introduction}

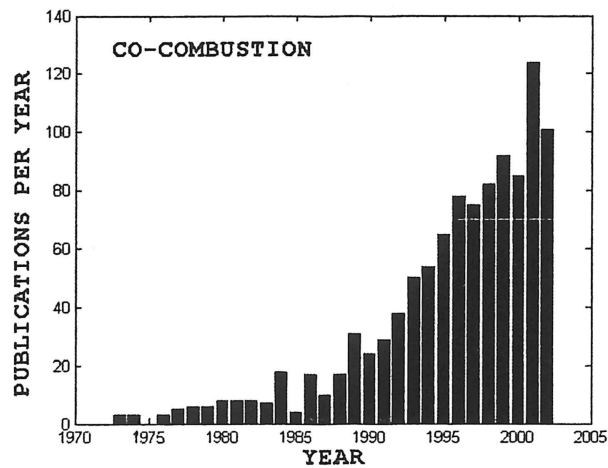

Figure 1. Number of publications per year dealing with "co-combustion" or "co-firing" as extracted from the data bank of ScienceFinder, January 2003.

* Department of Energy Conversion, Chalmers University of Technology, 41296 Göteborg, Sweden; e-mail: energy.conversion@entek.chalmers.se

(paper no. 203-3413)
Co-combustion of an additional fuel with a base fuel, such as coal in a boiler designed for coal, has attracted wide attention during recent years, as illustrated by the increase in the number of publications on the subject (Fig. 1). Although co-combustion has been employed "spontaneously" for several decades for removal of waste or to counteract taxes (in Sweden), on a world-wide perspective the idea became popular because of the interest in biofuels as a way to reduce effective $\mathrm{CO}_{2}$ emissions and as a potential solution of the problem of reducing waste and utilizing its energy content.

Complications may occur when a waste fuel is added to a base fuel combustor. The potentially influencing factors can be sorted into four groups:

- Energy content and volatiles. Some added fuels may be moist, and the quantity that can be added is restricted by the heat balance of the furnace. An extreme example is wet sewage sludge, whose effective heating value is very low. However, drying of such fuels can be arranged in energy-efficient ways.

- Content of precursors to gaseous emissions. These are mostly nitrogen, sulphur, and chlorine. They will be more or less converted into nitric or nitrous oxides, sulphur dioxide, and hydrogen chloride, hence contributing to undesired emissions.

- Ash-forming elements, such as compounds containing potassium, sodium, calcium, mangan, alumina, silica, and phosphorous, to mention the most important ones. Some of these elements may cause severe problems in the form of deposits followed by corrosion on heat transfer surfaces. They may lead to bed agglomeration in fluidized bed combustors. They may also affect the composition of the ash in a coal-fired unit, preventing the sale of ashes for secondary utilization, for instance, in the cement industry.

- Trace elements, of which the heavy metals are the most important ones: arsenic, beryllium, cadmium, mercury, lead, selenium, and so on. There are two types of problems related to trace elements: either they are volatilized and emitted to the atmosphere with the flue gases (like mercury and cadmium and other species, depending on the temperature conditions) or they are accumulated in the ashes, causing problems for deposition of ashes.

The impact of these groups varies depending on the type of additional fuel concerned. Co-combustion has 
been tested in a number of different combustion devices or combustion modes. They can be sorted up into five groups, four of which are illustrated in Fig. 2. The first method (Fig. 2(a)) is to simply inject the additional fuel into the combustion chamber together with the primary fuel or in parallel to it. This can be applied in suspension (flame) fired combustors or in fluidized bed combustors (FBC). Fig. 2(b) shows an arrangement where the additional fuel is added on a bed inserted in the bottom of the combustion camber. This could be a fluidized (noncirculating) bed or a fixed bed on a grate. The latter application has been tested with success [1]. The drawback is that the space for such a bed in a pulverized coal-fired boiler is rather small and the fraction of co-firing will always be restricted. Fig. 2(c) shows an arrangement that has been built on full-scale boilers in Denmark [2]. The arrangement consists of a boiler for the additional fuel, separate from the main boiler, such as seen from the principle sketch on Fig. 3. The water of the steam cycle flows through the main boiler and the co-combustor in parallel, which means that both have the same, and in the case of the plant concerned, very advanced steam data. The reheater indicated in Fig. 3 is allocated in the main boiler. The co-fuel in this case is straw or wood pellets, and the principal fuel is gas, although the main boiler can handle coal and biomass as well. The arrangement is a consequence of the local conditions in Denmark.

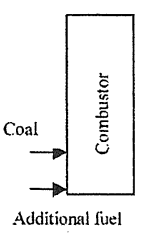

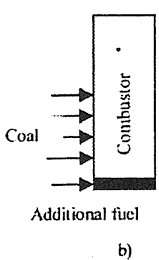

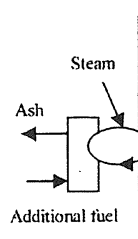

(a)

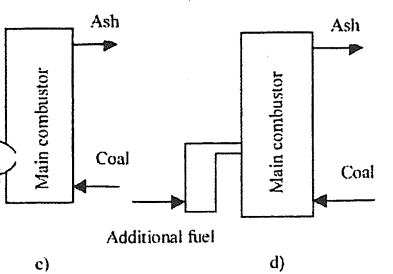

Figure 2. Four arrangements of co-combustion: (a) suspension firing or fluidized bed; (b) bed combustion of additional fuel in a suspension fired boiler; (c) separate combustor for the additional fuel, coupled to the main combustor on the steam side; (d) additional gas-producing unit, coupled to the main combustor on the flue gas side.

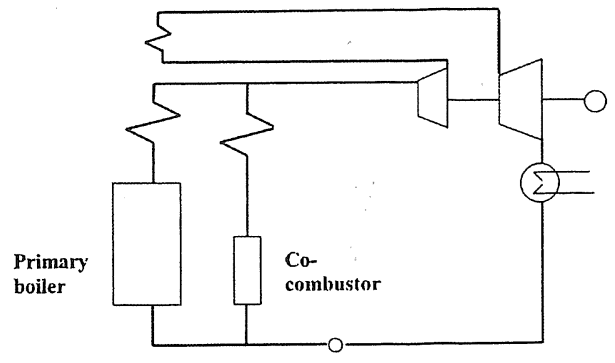

Figure 3. Parallel boiler for co-combustion inserted into the steam cycle with turbines, superheaters, and reheater.

One advantage of the separate combustor is that the ashes of the primary and the additional fuels are not mixed. This advantage is to some extent also maintained with the arrangement in Fig. 2(d) [3, 4], where the additional fuel is burned under substoichiometric conditions in a separate combustion chamber, often called "gasifier." The flue gases, containing a high ratio of unburned carbon monoxide, hydrogen, and hydrocarbons, are introduced into the main boiler through the aperture of the burner that it replaces. A principal reason to design this device for substoichiometric combustion is to reduce the thermal stress on the high-temperature duct combining the two combustion chambers by reducing the gas flow as much as reasonable. The "gasifiers" used were developed during the days of the "oil crisis" of the 1980s for replacement of oil by bio fuels in the lime kilns of the pulp and paper industry. Some of these are still in operation without problems.

Finally, additional fuel may also be used for reburning (whether this is actual reburning at high temperature or noncatalytic reduction, using the ammonia produced by gasification/devolatilisation is not important; there are several possibilities) [5, 6] or for "afterburning" [7], a technique for reduction of $\mathrm{N}_{2} \mathrm{O}$ in FBC.

This article will focus on a few of the above-mentioned items as an example of co-combustion. The utilization of municipal sewage sludge will be investigated with a circulating fluidized bed as a co-combustor. The question to be treated is whether the valuable constituents of sludge can be utilized at the same time as the sludge deposition problem is solved or at least reduced. Dry sludge consists of about $50 \%$ combustible matter with an energy content of $20 \mathrm{MJ} / \mathrm{kg}$ and $50 \%$ ashes with a content of phosphorous that is similar to that in fertilizers. Can the energy content of sludge be recovered in co-combustion, or can both the energy content and the valuable phosphorous be used? To answer this question, experiments were carried out in a test boiler with sludge in combination with coal or wood.

\section{Fuels of the Present Study}

Properties of the fuels of interest here are illustrated in Table 1. A few important constituents of the fuels should be commented upon. As was mentioned above, dry sludge consists of half ashes and half combustibles. Commercial coal qualities have ash contents of $10 \%$ to $20 \%$, whereas the ash content of wood is very small. If the phosphorous, whose concentration is about $4 \%$ dry sludge and $8 \%$ in the fuel ash, is to be utilized, co-combustion with wood would be better than co-combustion with coal in order to avoid dilution of the ashes. On the other hand, coal is the most common candidate to use as a base fuel for co-combustion. This is why both coal and wood are included in these tests.

Sludge contains a very high amount of nitrogen (Table 1) and as much sulfur as a conventional coal, and this can be suspected to result in high emissions of nitrogen and sulphur oxides. It also contains at least as much chlorine as coal. Hence, an assessment of the emissions is also important.

The sludge, whose properties are shown in Table 1, is dried. In this case the moisture content was $19 \%$, but it could have been even lower if the drying had been continued further. This type of drying takes place before the combustion process in an external dryer. In order to utilize the latent heat of the steam produced by the drying, 


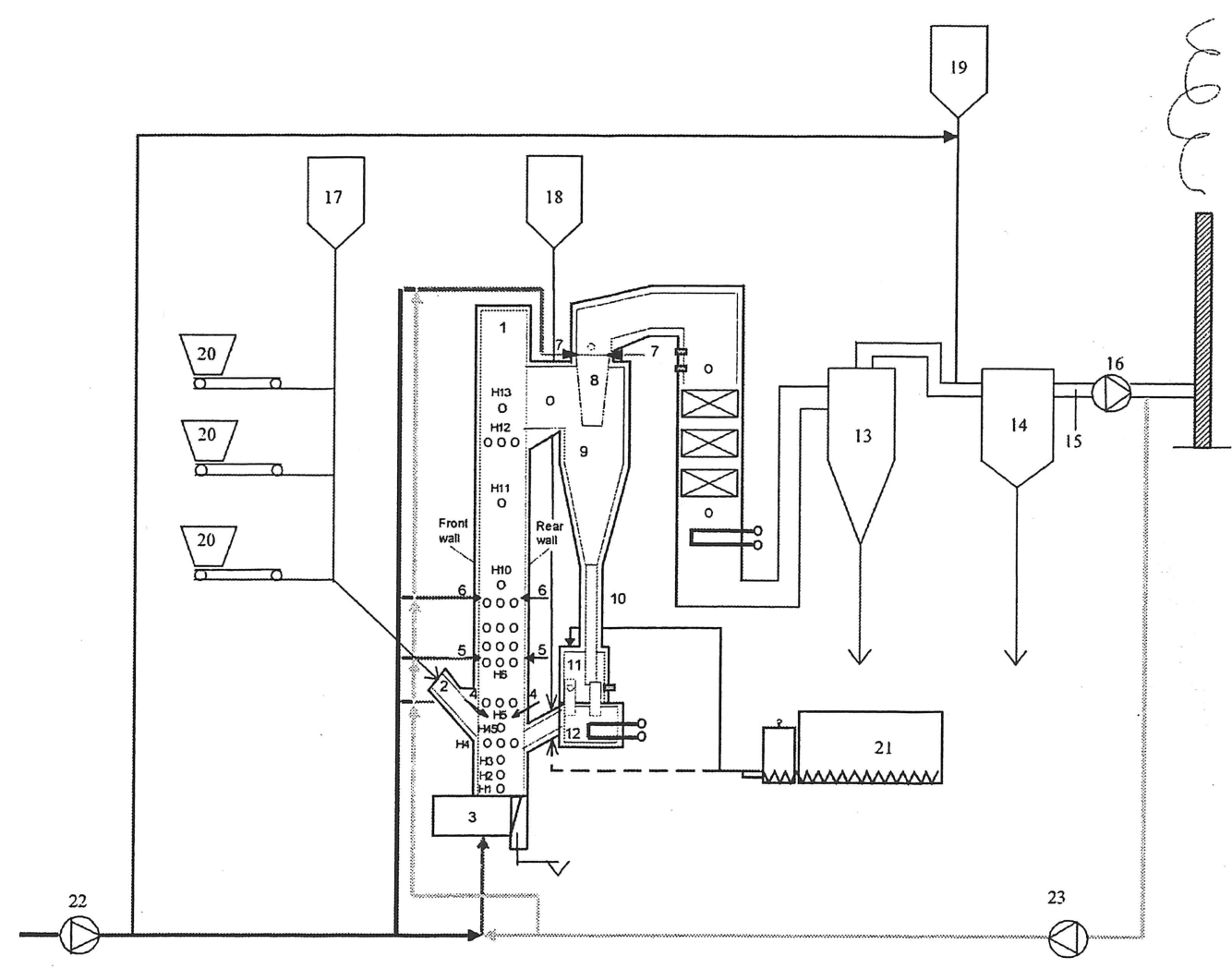

Figure 4. The 12-MW $\mathrm{MW}_{t h}$ CFB boiler at Chalmers University of Technology: (1) combustion chamber; (2) fuel feed chute; (3) air plenum; (4) secondary air inlet at $2.1 \mathrm{~m}$; (5) secondary air inlet at $3.7 \mathrm{~m}$; (6) secondary air inlet at $5.4 \mathrm{~m}$; (7) secondary air inlet into cyclone exit duct; (8) cyclone exit duct; (9) hot primary cyclone; (10) particle return leg; (11) particle seal; (12) particle cooler; (13) cold secondary cyclone; (14) bag house filter; (15) gas-extraction probe for emission monitoring; (16) flue gas fan; (17) sand bin; (18) lime bin; (19) hydrated lime bin; (20) fuel bunkers; (21) sludge pump; (22) air fan; (23) flue gas recirculation fan.

Table 1

Properties of the Fuels Used in Co-combustion Experiments

\begin{tabular}{|l|lll|}
\hline \multicolumn{1}{|c|}{ Fuel Type } & Coal & $\begin{array}{l}\text { Wood } \\
\text { (Pellets) }\end{array}$ & $\begin{array}{l}\text { Sewage } \\
\text { Sludge } \\
\text { Dried }\end{array}$ \\
\hline Proximate analysis & & & \\
Water (wt-\%, raw) & 9.0 & 8.1 & 19.0 \\
Ash (wt-\%, dry) & 17.5 & 0.4 & 37.9 \\
Volatiles (wt-\%, daf) & 32.7 & 81.7 & 90.6 \\
Ultimate (wt-\%, daf) & & & \\
$\mathrm{C}$ & 84.9 & 50.2 & 53.2 \\
$\mathrm{H}$ & 5.0 & 6.1 & 7.1 \\
$\mathrm{O}$ & 7.7 & 43.6 & 30.6 \\
$\mathrm{~S}$ & 0.7 & 0.01 & 1.9 \\
$\mathrm{~N}$ & 1.6 & 0.12 & 7.11 \\
$\mathrm{Cl}$ & 0.08 & 0.002 & 0.05 \\
Lower heating value (MJ/kg) & & & \\
$\mathrm{H}_{u}$, daf & 33.4 & 18.8 & 20.9 \\
$\mathrm{H}_{u}$, raw & 24.7 & 17.2 & 9.8 \\
daf = dry and ash free & & & \\
\hline
\end{tabular}

its heat of condensation should be transferred to the steam cycle through a heat exchanger [8, 9]. Alternatively, if drying takes place in the furnace in connection with combustion, the heat of evaporation can be partly recovered from the flue gases by condensation, as is commonly done with wet fuels in the Swedish district heating systems [9, 10]. However, for a combustor at atmospheric pressure this heat recovery takes place at such a low temperature level (below $100^{\circ} \mathrm{C}$ ) that it can only be used for space heating.

\section{The Combustion Plant}

The co-combustion tests were conducted in the $12 \mathrm{MW}_{t h}$ circulating fluidized bed (CFB) test plant at Chalmers University of Technology, where municipal sewage sludge was burned together with either wood or coal. The plant is shown in Fig. 4.

The boiler consists of a riser or combustion chamber (1), a primary cyclone (9) for recirculation of bed material, a fuel inlet (2) and a conventional convection section, where the gases are cooled before they are cleaned in a secondary cyclone (13), and a bag filter (14). Combustion air is supplied as primary air from the bottom of the combustion chamber (3) and from a number of optional secondary air inlets $(4,5,6,7)$. In the present tests about stoichoimetric amount of air was supplied as primary air 
through the bottom (3), and the remaining air for burnout was supplied through nozzles in the cyclone outlet (7). This arrangement of air supply has been called "advanced staging" (or "reversed staging") and has been proposed for optimization of the emissions of $\mathrm{NO}, \mathrm{N}_{2} \mathrm{O}$, and $\mathrm{SO}_{2}$ from coal firing [11]. Fuel, including dry sludge, can be fed through a number of hoppers (20) suitable for cocombustion. In the case where wet sludge is used, it can be fed by means of a reconstructed cement pump (21). The boiler is equipped with measurement devices for heat and mass balances, a data collection and evaluation system, and a number of ports for gas and solids sampling probes. A typical set of operational data are presented in Table 2.

Despite variation of the fraction of base and additional fuel between the test cases, the operation conditions of Table 2 could be maintained by compensation for the changes in the heat balance of the furnace.

Table 2

Boiler Operation Data

\begin{tabular}{|c|c|c|}
\hline Base Fuel & Coal & Wood \\
\hline Added Fuel & Dried Sludge & Dried Sludge \\
\hline Load, $\mathrm{MW}_{t h}$ & 6.5 & 5.5 \\
\hline Riser temperature, bottom, ${ }^{\circ} \mathrm{C}$ & 841 & 841 \\
\hline Riser temperature, top, ${ }^{\circ} \mathrm{C}$ & 855 & 857 \\
\hline $\begin{array}{l}\text { Exit temperature of afterburn- } \\
\text { ing chamber, }{ }^{\circ} \mathrm{C}\end{array}$ & 772 & 797 \\
\hline $\begin{array}{l}\text { Total pressure drop of riser, } \\
\text { mbar }\end{array}$ & 68 & 68 \\
\hline Molar ratio, $\mathrm{Ca} / \mathrm{S}$ & 2.3 & 1.9 \\
\hline Total air ratio & 1.23 & 1.23 \\
\hline Combustor air ratio & 1.05 & 1.03 \\
\hline
\end{tabular}

\section{Results}

The influence of co-combustion on the emissions of NO, $\mathrm{N}_{2} \mathrm{O}, \mathrm{SO}_{2}$, and $\mathrm{Cl}$ in the form of $\mathrm{HCl}$ both for coal and for wood as base fuel is illustrated in Figs. 5-8.

Most of the trends in emissions observed as a function of sludge fraction can be qualitatively explained, based on previous experience and in relation to the contents of nitrogen, sulfur, and chlorine of the fuels given in Table 1. Also, one has to consider that the emission is a result of formation minus reduction of the pollutant concerned. This is straightforward in the case of chlorine, of which only small amounts are bound in alkali compounds in solid form, and most part of the chlorine in the fuel is emitted in gaseous $\mathrm{HCl}$ (Fig. 8). Despite the difference in fuel nitrogen content, the NO emissions from mono-combustion in FBC of wood and coal are fairly similar (Fig. 5), as explained in [12]. As a consequence of the high fuel nitrogen content of sludge, the formation of NO increases when sludge is added. The rise of the NO concentration is mitigated by the ability of the char in the bed to reduce the NO formed, and as a result the total conversion of fuel nitrogen to $\mathrm{NO}$ is only a few percent. The emission of $\mathrm{N}_{2} \mathrm{O}$ is insignificant for pure wood [12] but higher for coal. With the addition of sludge the emission remains more or less at the level of coal, and surprisingly enough it does not increase further. The reason is unknown; it may be related to the form of nitrogen in sludge and its conversion in the bed. It may also be a consequence of the air staging. The sulphur emission is a result of the sulfur in the fuel minus the absorption by the limestone added (Table 2). The calcium-to-sulphur ratio was kept constant, and then the sulphur emission should be constant if the sulphur capture efficiency is constant, but the $\mathrm{SO}_{2}$ emission increased with the addition of sludge. The greater impact of sludge addition on the $\mathrm{SO}_{2}$ emission during co-combustion with wood compared to coal is obviously caused by less efficient sulfur removal by limestone for high-volatility fuels, but with an increasing sludge fraction the sulphur capture efficiency also grew worse for coal, and other, yet unknown, factors may have contributed too.

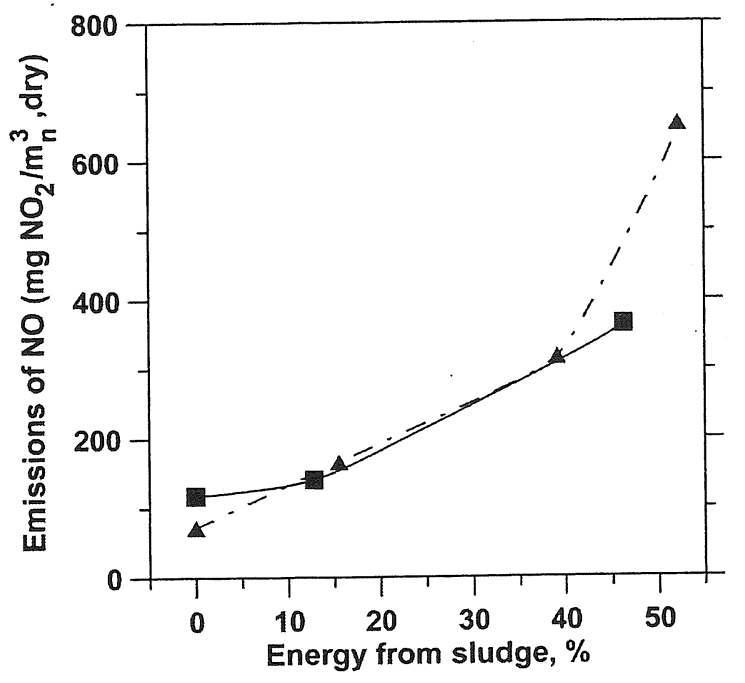

Figure 5. Emissions of nitrogen from co-combustion of wood (1) or coal (1) with sludge as a function of the amount of sludge added.

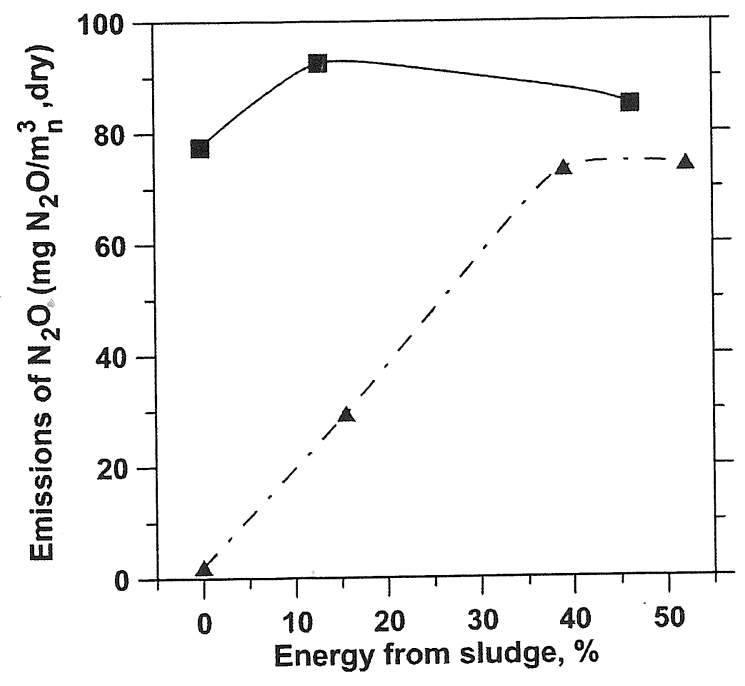

Figure 6. Emissions of nitrous oxide from co-combustion of wood ( $\mathbf{\Delta}$ ) or coal ( with sludge as a function of the amount of sludge added. 


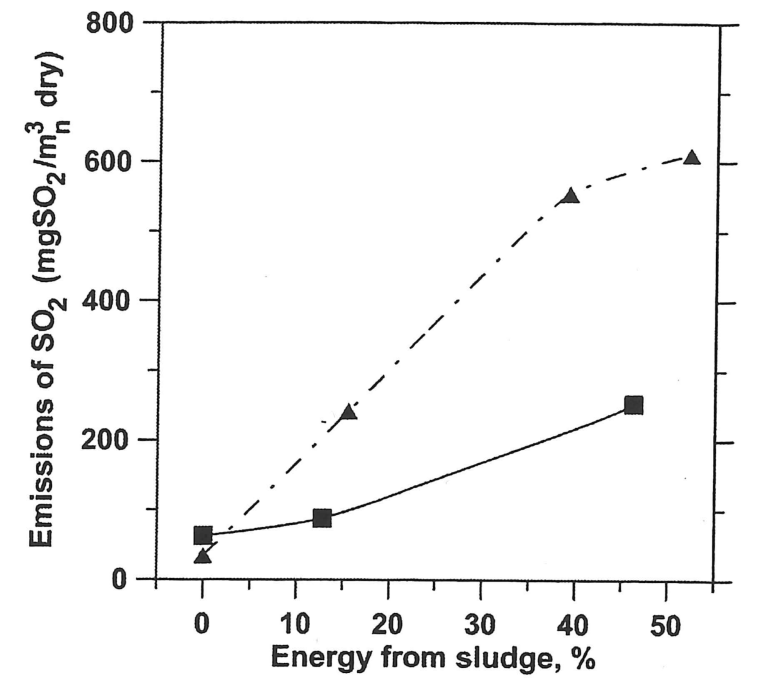

Figure 7. Emissions of sulphur dioxide from co-combustion of wood $(\boldsymbol{\Delta})$ or coal ( $\boldsymbol{\square})$ with sludge as a function of the amount of sludge added.

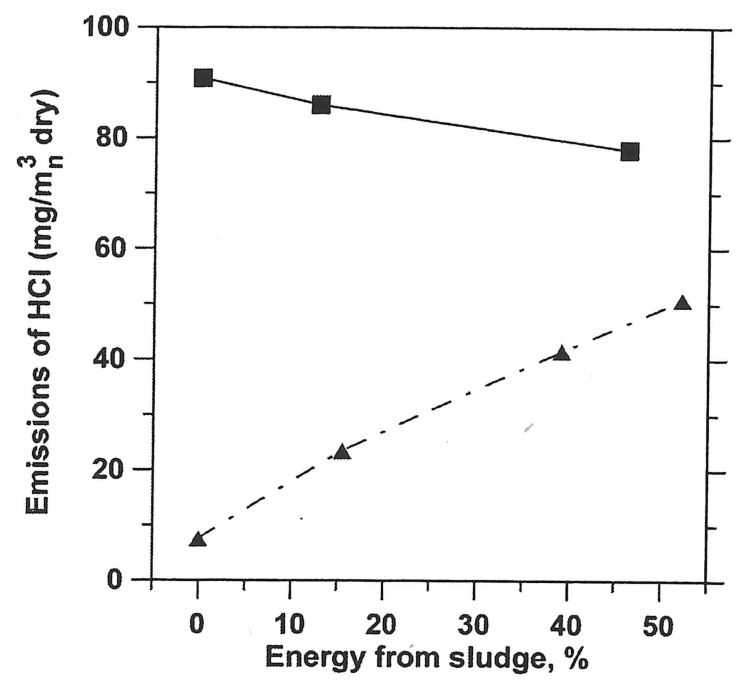

Figure 8. Emissions of hydrogen chloride from cocombustion of wood $(\mathbf{\Delta})$ or coal $(\square)$ with sludge as a function of the amount of sludge added.

The European Union (EU) has formulated emission standards for incinerators and for conventional monocombustion plants [13]. There is a possibility of establishing emission limits for co-combustion with various fractions of additional fuel by interpolation between the two single-fuel combustion cases (base fuel and waste fuel). If this is done in the present cases, we can see that for moderate fractions of additional fuel, about $<25 \%$, the emission limits are fulfilled with the exception of that of sulfur for co-combustion of sludge and wood, whose emission limit is surprisingly low [14]. For chlorine emission from incinerators burning $100 \%$ waste the standard is 10 $\mathrm{mg} \mathrm{HCl} / \mathrm{Nm}^{3}$ [13], but there is no standard of chlorine emissions for conventional mono-combustors burning coal or wood. A convention among certain local authorities has been to accept the actual $\mathrm{HCl}$ emission as a standard value for a given mono-combustion plant. Then, however, if cocombustion was introduced in such a plant, the emission limits would be exceeded for almost all additional fuels containing more chlorine than that corresponding to the lower limit, if the limit for various fractions of additional fuel is represented by an interpolation between the value for the mono-combustion plant and the waste incinerator [14].

In conclusion, reasonable fractions of added waste fuels can be handled without exceeding the emission limits for gaseous emissions, but there will be some problem in the EU with desulphurization during co-combustion of wood and sewage sludge, as long as the sulfur content is as high as the present one. The chlorine emission can be handled if the plant is equipped with a scrubber, or if injection of hydrated lime is installed in plants having bag filters. Again, the emission limits are not clearly established in this case, and legislative solutions might be found.

The original form of phosphorous in the sludge is mainly ferric phosphate $\left(\mathrm{FePO}_{4}\right)$, as the precipitation species in the sludge treatment process is ferrous iron. $\mathrm{FePO}_{4}$ performs well as a fertilizer when sludge is directly used on the soil. When the sludge is burned, the iron is oxidized to iron oxide $\left(\mathrm{Fe}_{2} \mathrm{O}_{3}\right)$ and the phosphate could combine with other species like calcium or aluminium. For example, lime added to the furnace for sulphur capture could react with phosphorous to form calcium phosphate. The concentration of phosphorous is around $9 \%$ in the fuel ash, a few percent in the bottom ashes, and in the case of wood it is about $7 \%$ in the ashes leaving the secondary cyclone and the bag filter ((13) and (14) depicted in Fig. 4. The corresponding concentrations are lower for the base fuel coal because of the dilution of coal ash, and in this case the concentration of phosphorous was found to increase only slowly with the fraction of co-fuel [15].

If $22 \mathrm{~kg}$ phosphorous per acre is assumed to be a reasonable yearly dosage for a fertilizer (at least in Sweden [15]), it is possible to calculate the amounts of ashes that should be employed as a fertilizer, and hence the corresponding amount of trace elements $\mathrm{Hg}, \mathrm{Cd}, \mathrm{Pb}, \mathrm{Cr}$, $\mathrm{Cu}, \mathrm{Ni}$, and $\mathrm{Zn}$ that would be deposited. This could be compared with the corresponding maximum levels for trace elements on agricultural grounds. An example of such a comparison is shown in Fig. 9, valid for cadmium. The figure compares cadmium loads from sludge, animal manure, artificial fertilizer, and fly ash. The conclusion is similar to that of several of the other trace elements: the maximum concentrations allowed are exceeded for sludge, whereas animal manure and especially artificial fertilizer are below or far below the limiting values.

The conclusion is that municipal sewage sludge or ashes from it cannot be used as a fertilizer in the agriculture without reduction of the amount of trace elements or extraction of the phosphorous from the ashes.

\section{General Conclusion}

Co-combustion in fluidized beds is an uncomplicated way of utilizing bio fuels or wastes. Normally, only minor quantities of co-fuels are burned, and even in the case of 


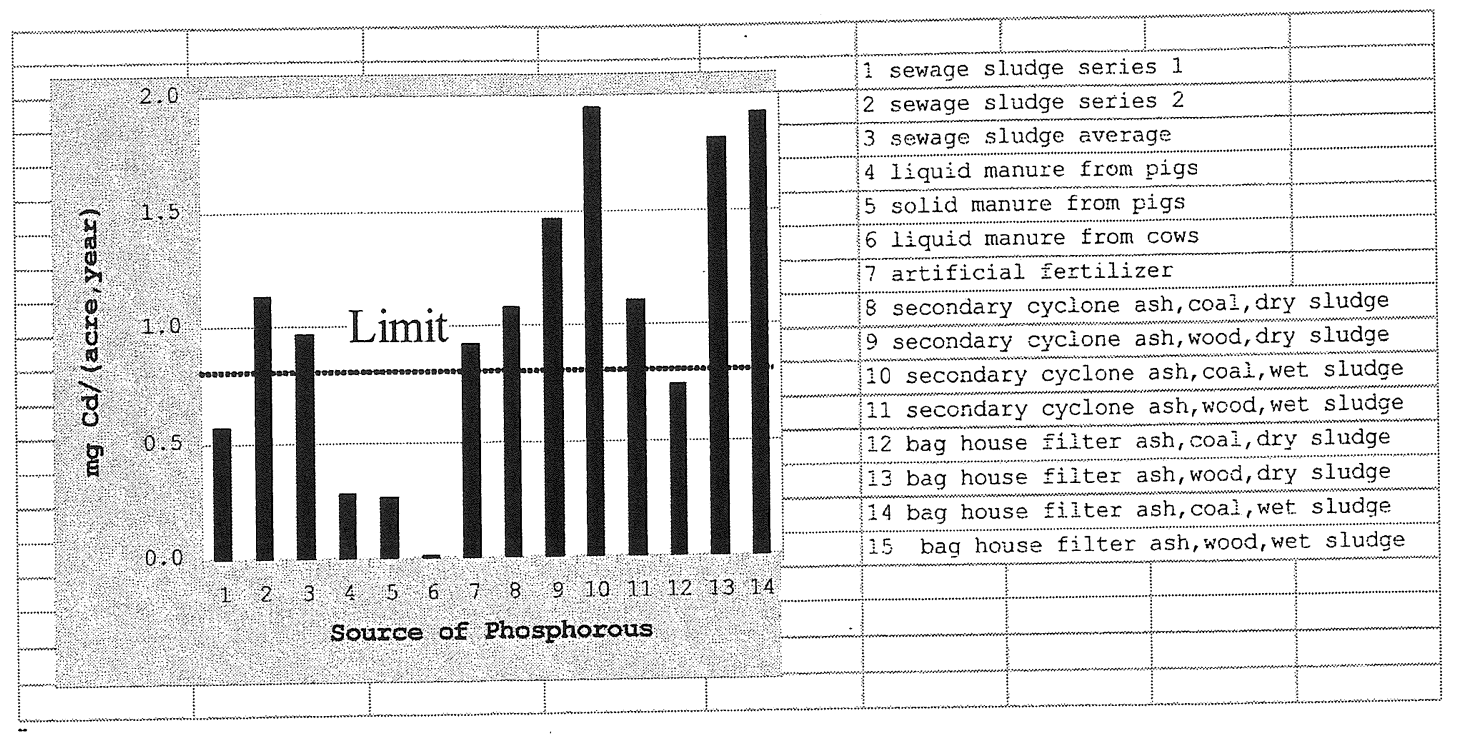

Figure 9. Contamination of cadmium when $22 \mathrm{~kg}$ phosphorous is supplied to one acre during one year. Comparison of various P-sources. 1-3 sewage sludge, 4-6 animal manure, 7 artificial fertilizer, 10-15 fly ash. Source: [15]

sewage sludge containing considerable quantities of nitrogen, sulphur, and chlorine, emission limits can be satisfied. Depending on particular features of such limits, special measures might be necessary in some cases to reduce the emissions below the limits. Two such examples were mentioned: co-combustion of sludge with wood tends to exceed the extremely low EU emission limit. Similarly, the emission limits of chlorine may be exceeded during co-combustion, but the limits are not well established for chlorine emission during co-combustion; if such were the case, simple measures could be taken to bring the emission below the limit.

Sludge ash cannot be utilized as a fertilizer on agricultural grounds, at least not according to Swedish conditions. Reduction of the concentrations of the trace elements or extraction of the phosphorous is theoretically possible but has not been further investigated.

\section{Acknowledgement}

Most of the work related to the $12 \mathrm{MW}$ boiler at Chalmers University was financially supported by the Swedish Energy Administration.

\section{References}

[1] A. Mory \& J. Tauschitz, Co-combustion of biomass in coal-fired power plants in Austria, VGB PowerTech, 79 (1), 1999, 50-55.

[2] Anonymous, Avedöre 2 sets new benchmarks for efficiency, flexibility and environmental impact, Modern Power Systems, January 2000, 25-36.

[3] N. Raskin, J. Palonen, \& J. Nieminen, Power boiler fuel augmentation with a biomass fired atmospheric circulating fluid-bed gasifier, Biomass \& Bioenergy, 20, 2000, 471-481.

[4] H. Anderl, A. Mory, \& T. Zotter, BioCoComb-Vergasung von Biomasse und Mitverbrennung von Gas in einem Kohlenstaubkessel, VGB-Kraftwerkstechnik, 80(3), 2000, 68-75.
[5] N. Berge, M. Carlsson, P. Kallner, \& B. Strömberg, Reburning of a pulverised coal flame with LVC gas, in Inst. for Process Engineering and Power Plant Technology TU Stutgart (Ed.), Co-gasification of coal/biomass and coal/waste mixtures, Vol. III, Part C7 (European Commission (DGXII), 1992-1994).

[6] H. Spliethoff \& K.R.G. Hein, Effect of co-combustion of biomass on emissions in pulverized fuel furnaces, Fuel Processing Technology, 54, 1998, 189-205.

[7] L. Gustavsson \& B. Leckner, Abatement of $\mathrm{N}_{2} \mathrm{O}$ emissions from circulating fluidized bed combustion through afterburning, IEEC Research, 34, 1995, 1419-1427.

[8] R. Wimmerstedt, Steam drying: History and future, Drying Technology, 13(5-7), 1995, 1059-1076.

[9] R. Wimmerstedt, Recent advances in biomass drying, Chemical Engineering and Processing, 38, 1999, 441-447.

[10] Rökgaskondensering ("Condensation of flue gas"), The Swedish Energy Administration, Stockholm, 1991 (in Swedish).

[11] A. Lyngfelt, L.-E. Åmand, \& B. Leckner, Reversed air staging: A method for reduction of $\mathrm{N}_{2} \mathrm{O}$ emissions from fluidized bed combustion of coal, Fuel, 77, 1998, 953-959.

[12] B. Leckner \& M. Karlsson. Gaseous emissions from circulating fluidized bed combustion of wood, Biomass \& Bioenergy, 4, 1993, 379-389.

[13] Directive 2000/76/EC of the European Parliament and of the Council of 4 December 2000 on the incineration of waste, Official Journal of the European Communities, L332/91, December 28,2000 .

[14] B. Leckner, L.-E. Åmand, K. Luecke, \& J. Werther, Gaseous emissions from co-combustion of sewage sludge and coal/wood in fluidized bed, Fuel, 2003 (in press).

[15] L.-E. Åmand, B. Leckner, L. Hansson, \& O. Norrlöw, Cocombustion of municipal sludge with wood/coal in CFB: Enrichment of phosphorous and cadmium in ashes, International Conf. on FBC, ed. S.V. Prisupati, (New York: American Society of Mechanical Engineers, 2003). 


\section{Biographies}

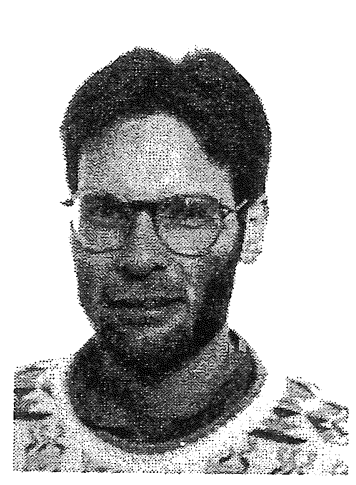

Lars-Erik Amand graduated with a degree in chemical engineering from Chalmers University of Technology, Sweden, in 1982. He obtained his doctorate in 1994 with a thesis entitled " $\mathrm{N}_{2} \mathrm{O}$ emissions from fluidized bed combustion." In 1996 he obtained the position of Associate Professor (Docent).

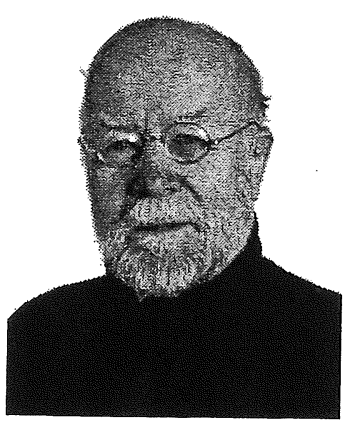

Bo Leckner was born in 1936 and graduated from the Mechanical Engineering Department at Chalmers University of Technology in 1962. He obtained his doctorate in 1972 with a thesis entitled "Radiative heat transfer in furnaces." Since then he has been Acting Professor and Professor in energy conversion technology at Chalmers University of Technology. 